\title{
Mitotic Effect of Leaf Extracts of Ipomoea carnea on Allium cepa
}

\author{
Sultanul Alam, Golam Kabir, M. Nurul Amin and Monirul Islam \\ Department of Botany, Rajshahi University, Bangladesh
}

Accepted February 20, 1987

The effect of plant extract on seed germination, seedling growth and on chromosome behaviour has attracted considerable interest. Le Tourneau et al. (1956) studied the effect of aqueous extracts of plant tissues on germination of seed and growth of seedlings. They found that the aqueous extracts of some plants inhibited seed germination and seedling growth of wheat and peas. Bhalla et al. (1973) treated onion root tips with different concentrations of tobacco smoke condensate and observed a number of abnormalities in somatic chromosomes. Datta and Chakravarti (1975) reported the presence of germination and growth inhibitor in Clerodendron viscosum Vent. Pandya (1975) worked on the effect of Celosea argentea extracts on root and shoot growth of bajra seedlings and observed that the aqueous extracts of fresh leaves, stem and root caused inhibition being more at higher concentrations. He also reported that the leaf and root extracts were more toxic than the stem extracts. Shehab et al. (1978) studied the cytological effects of Achillea fragrantissima extracts on Allium cepa and Vicia faba. In 1979 Shehab had shown that the extracts of Pulicaria crispa affected the mitotic index and the percentage of abnormalities increased with an increase of concentration and duration of treatment in onion. Shehab (1980) found the extract of Teucrium pilosum to cause the antimitotic effect. Kabarity and Malallah (1980) reported mitodepressive effect of Cata edulis extracts in meristematic region of Allium cepa root tips. Adam et al. (1974) and Tartour et al. (1975) studied the effects of Ipomoea carnea on the liver and on the serum enzymes in young ruminants. They found the development of anaemia, leukopenian, general weakness, tremors, paresis of hind limbs, lateral recumbancy, focal haepotic necrosis and congestion of the brain in goats feed with Ipomoea carnea leaves and the goats were died within 75 days. These were more marked in sheep and goat than the claves. But the informations regarding cytological effects of aqueous extracts of Ipomoea carnea and their constituents are not adequate.

Therefore an attempt was made to observe the effect of the leaf extracts of Ipomoea carnea in somatic chromosomes of Allium cepa.

\section{Materials and methods}

Fresh leaves of road side fencing shrub Ipomoea carnea (Fam. Convolvulaceae) and locally available bulbs of onion, Allium cepa L. (Fam. Liliaceae) were used as plant material in this experiment.

To prepare leaf extracts $10 \mathrm{gms}$ of fresh and mature leaves of Ipomoea carnea were ground in a mortar by the pestle with $100 \mathrm{ml}$ distilled water. Three different concentrations viz., $\mathrm{D}_{1}$ $(0.5 \%), D_{2}(1 \%)$ and $\mathrm{D}_{3}(1.5 \%)$ were prepared by mixing $5 \mathrm{ml}, 10 \mathrm{ml}$ and $15 \mathrm{ml}$ of the extract with $95 \mathrm{ml}, 90 \mathrm{ml}$ and $85 \mathrm{ml}$ of distilled water, respectively. The control was designated as $\mathrm{D}_{0}$.

Onion bulbs were placed in small beakers with their basal ends dipping in distilled water at room temperature for nine hours. The distilled water was changed and the bulbs were placed again in beakers containing different concentrations of leaf extracts. The control $\left(D_{0}\right)$ was kept undisturbed and untreated. The root tips of approximately 0.5 to $1.5 \mathrm{~cm}$ long were collected at 10 AM in 1:3 aceto-alcohol solution. After 48 hours of fixation root tips were transferred to $70 \%$ alcohol and stored in the refrigerator. 
In order to collect cytological data from the root tip cells of Allium cepa, temporary slides were prepared by hydrolysing the root tips in $50 \% \mathrm{HCl}$ for 8 minutes, mordanting in $2 \%$ iron alum for 5 minutes and staining in $0.5 \%$ haematoxylin for 7 minutes. For each treatment slides were prepared from 10 different root tips and examined under microscope. Photomicrographs were taken from the prepared slides.
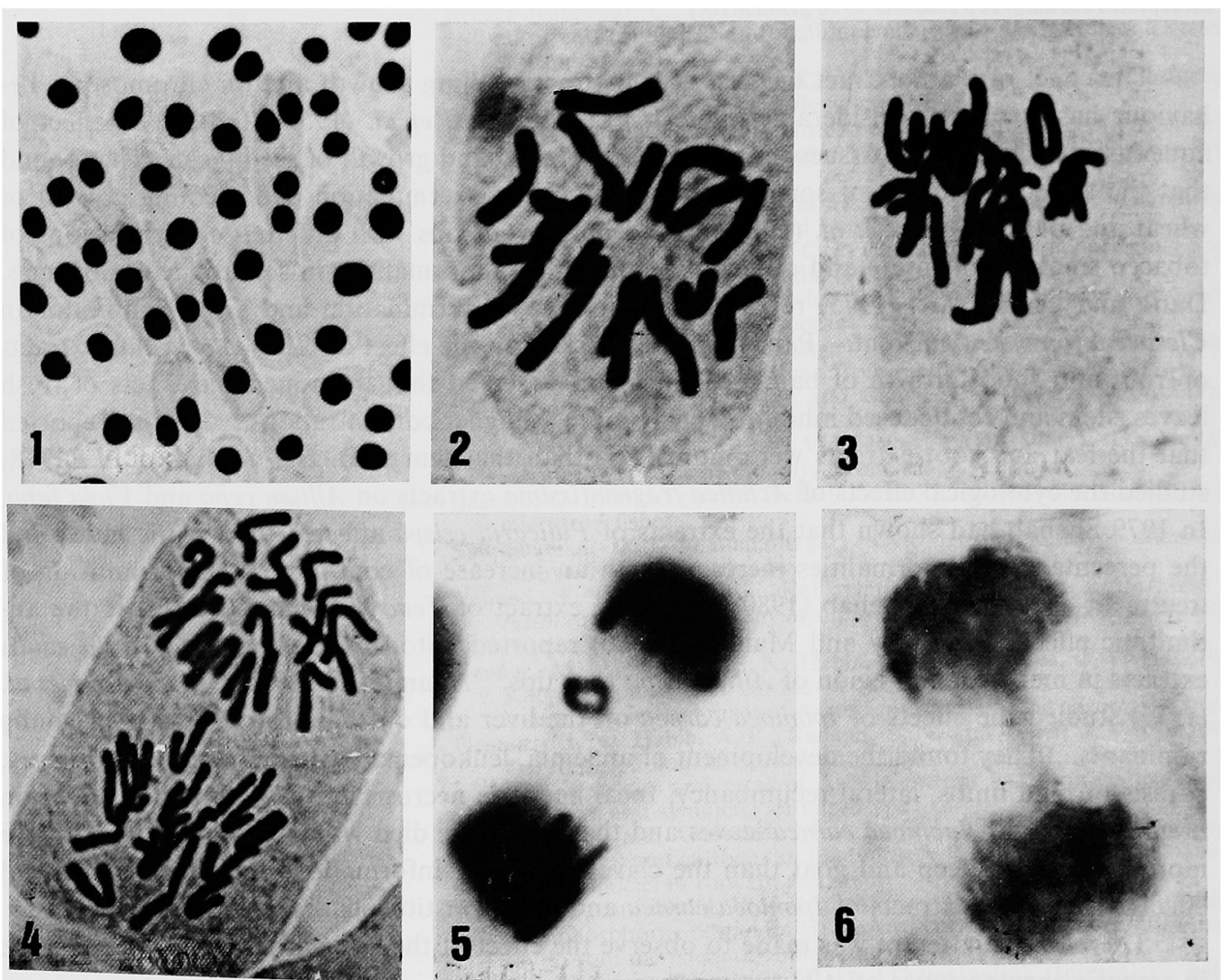

Figs. 1-6. 1, nondividing cells of treated onion root tip. $\times$ ca 400.2 , metaphase with spindle inhibition. $\times$ ca 3000 . 3, metaphase with ring chromosome. $\times$ ca 2900.4 , normal anaphase. $\times$ ca 2800 . 5, telophase with ring chromosome. $\times$ ca 1630.6 , telophase with chromosome bridge. $\times$ ca 3300 .

Table 1. Mitotic index and percentages of different stages of cell division along with the chromosomal irregularities

\begin{tabular}{|c|c|c|c|c|c|c|c|c|c|}
\hline \multirow{2}{*}{$\begin{array}{l}\text { Concen- } \\
\text { trations }\end{array}$} & \multirow{2}{*}{$\begin{array}{l}\text { No. of } \\
\text { cells } \\
\text { observed }\end{array}$} & \multirow{2}{*}{$\begin{array}{l}\text { Percen- } \\
\text { tage of } \\
\text { dividing } \\
\text { cells }\end{array}$} & \multicolumn{4}{|c|}{$\begin{array}{l}\text { Percentages of different } \\
\text { stages of cell division }\end{array}$} & \multicolumn{3}{|c|}{$\begin{array}{l}\text { Percentages of chromosomal } \\
\text { irregularities }\end{array}$} \\
\hline & & & $\begin{array}{l}\text { Pro- } \\
\text { phase }\end{array}$ & $\begin{array}{l}\text { Meta- } \\
\text { phase }\end{array}$ & $\begin{array}{l}\text { Ana- } \\
\text { phase }\end{array}$ & $\begin{array}{l}\text { Telo- } \\
\text { phase }\end{array}$ & $\begin{array}{l}\text { C-meta- } \\
\text { phase }\end{array}$ & $\begin{array}{l}\text { Ring } \\
\text { chromo- } \\
\text { some }\end{array}$ & $\begin{array}{c}\text { Chromo- } \\
\text { some- } \\
\text { bridge }\end{array}$ \\
\hline $\mathrm{D}_{0}$ & 14927 & 3.77 & 1.02 & 0.86 & 0.60 & 1.29 & - & - & - \\
\hline$D_{1}$ & 14116 & 3.58 & 1.01 & 0.79 & 0.57 & 1.21 & 1.29 & 0.54 & 0.93 \\
\hline $\mathrm{D}_{2}$ & 15151 & 2.26 & 0.56 & 0.71 & 0.40 & 0.59 & 1.26 & 1.35 & 0.96 \\
\hline $\mathrm{D}_{3}$ & 13853 & 1.73 & 0.72 & 0.29 & 0.21 & 0.51 & 1.98 & 1.71 & 1.62 \\
\hline
\end{tabular}




\section{Results and discussion}

The cytological observations from treated root tip cells revealed that the extracts of Ipomoea carnea had a strong mitodepressive effect on Allium cepa roots. Mitotic index and percentages of different stages of cell division along with the chromosomal irregularities after treating the root tips of onion with different concentrations of leaf extracts are shown in the Table 1. Depression of mitotic index increased with an increase of concentration. Shehab (1979) found similar results with the extracts of Pulicaria crispa on the mitotic index and percentage of anomalies in onion which increased with an increase of the concentration and duration of treatment. Depression of cell division was seen obviously in the highest concentration $\left(D_{3}\right)$ used where the mitotic index reached not more than $1.73 \%$ compared to $3.77 \%$ in the control $\left(D_{0}\right)$. In higher doses it was found to have more deletorious effects. Dividing cells were completely absent in certain treatment of higher concentration (Fig. 1). It was found to arrest metaphases (C-mitotic effect) (Fig. 2) and bring about condensation and stickiness of chromosomes resulting in the formation of ring chromosomes (Fig. 3). However, their frequencies were found highest in the highest concentration $\left(D_{3}\right)$. Mitotic observation of the onion root tip cells treated with different concentrations of leaf extracts showed chromosome bridges and ring chromosomes in telophase stages (Figs. 5,6). Such abnormalities were also observed by Sudharsan and Reddy (1971) after treatment of Vicia faba root tips with leaf extracts of Lathyrus sativus. In the present investigation mitodepressive effect was observed. Similar results were also reported by Kabarity and Malallah (1980) in the root tip cells of onion due to the effect of Cata edulis leaf extracts.

Tewari et al. (1964) isolated $\beta$-sitosterol, triacantain and saponin from the leaves of Ipomoea carnea. They have suggested that the saponin is probably triterpenoid in nature and it may have some inhibitory effect.

\section{Conclusions and summary}

This study was conducted to see the toxic effects of leaf extracts of Ipomoea carnea in the root tip cells of onion. Three different concentrations viz., $\mathrm{D}_{1}(0.5 \%), \mathrm{D}_{2}(1 \%)$ and $\mathrm{D}_{3}(1.5 \%)$ were used. The control was designated as $D_{0}$. It was observed that the leaf extracts affected the mitotic frequency and caused some anomalies of root tip cells of onion. The percentages of dividing cells decreased with an increase of the concentration of leaf extracts. Irregularities were spindle inhibition, disturbed prophase and metaphase, sticky bridges at anaphase and telophase, and ring chromosomes in metaphase and telophase.

The present investigation, thus, demonstrated that the leaf extracts of Ipomoea carnea had a marked effect on the mitotic index as well as chromosomal irregularities in onion root tip cells.

\section{References}

Adam, S. E. I., Tratour, G, Obeid, H. M. and Idris, O. F. 1974. Effects of Ipomoea carnea on the liver and on serum enzymes in young ruminants. J. Comp. Pathol. 83(4): 531-542. (Biol. Abst. 58(5): 29087).

Bhalla, P. R., Kochhar, T. S. and Sabharwal, P. S. 1973. Induction of mitotic abnormality in onion root tips by tobacco smoke condensate. Cytologia 38: 707-712.

Datta, S. C. and Chakravarti, S. D. 1975. Germination and growth inhibitors from Clerodendron viscisum Vent. Geobios 2: 188-189.

Kabarity, A. and Malallah, G. 1980. Mitodepressive effect of khat extract in the meristematic region of Allium cepa root tips. Cytologia 45: 733-738.

Le Tourneau, D., Failes, G. D. and Heggeness, H. G. 1956. The effect of aqueous extracts of plant tissues on germination of seeds and growth of seedlings. Weeds 4: 363-368. 
Pandya, S. M. 1975. Effect of Celosia argentea extracts on root and shoot growth of bajra seedlings. Geobios 2: $175-178$.

Shehab, A. S. 1979. Cytological effects of medicinal plants in Qatar 1. Mitotic effects of water extracts of Pulicaria crispa on Allium cepa. Cytologia 44: 607-613.

- 1980. Cytological effects of medicinal plants in Qatar II. Mitotic effects of water extracts of Teucrium pilosum on Allium cepa. Cytologia 45: 57-64.

-, Hakeem, H. A. and Abu-El-Kheir, Z. 1978. Cytological effects of Achillea fragrantissima extract on Allium cepa and Vicia faba. Cytologia 43: 623-629.

Sudharsan, R. A. and Reddy, S. S. 1971. Cytological studies in Vicia faba, treated with leaf extracts of two varieties of Lathyrus sativus. Cytologia 36: 702-715.

Tartour, G., Adam, S. E. I., Obeid, H. M. and Idris, O. F. 1975. Development of anaemia in goats feed with Ipomoea carnea: BR. Vet. J. 130(3): 271-279. (Biol. Abstr. 59(4): 23247).

Tewary, J. P., Datta, K. C. and Mishra, S. S. 1964. Phytochemical and pharmacological investigations of Ipomoea carnea leaves. Sci. Tech. 2: 4. 